\title{
Theoretical Reductionism: Forcing a Covering Law Doctrine of Behavioral Psychology on the Sociology of Everyday Communication and Interaction
}

\author{
J Forbes Farmer \\ Professor, Social and Behavioral Science Division \\ Franklin Pierce University \\ 40 University Drive \\ Rindge, NH, 03461 USA \\ E-mail: Farmerjf@Franklinpierce.edu
}

Received: August 30, 2018 Accepted: September 29, 2018 Published: October 1, 2018

doi: 10.5296/jsss.v6i1.13730 URL: http://doi.org/10.5296/jsss.v6i1.13730

\begin{abstract}
This paper is an attempt to show that despite the stated differences in the explanations of interaction motives and rituals espoused by micro-sociologists, the major approach to the study of communication, language and social exchange is behavioral psychology. This includes the use of the covering law propositions of hedonism and cost-benefit analysis. With evidence from original writings, the author creates a Homansian assimilation of Goffman's dramaturgical analysis.
\end{abstract}

Keywords: Interaction rituals, Hedonism, Covering law doctrine, Exchange theory, Behavioral psychology

\section{Introduction}

All men, or most men, wish what is noble but choose what is profitable, and while it is noble to render a service not with an eye to receiving one in turn, it is profitable to receive one. One ought...if one can, to return the equivalent of services received and to do so willingly. (Aristotle, as cited in Joachim, 1998, p. 217)

Social scientists have long used the term "theory" in different ways and there have been many empirical investigations into the logic of each one. Malewski (2017) suggested that the concept "theory" could be defined as a hypothesis or a speculation concerning reality that is 
unconfirmed by empirical data (Hall \& Lindzey, 1957). An alternative definition proposed by Merton (1957) was that "theory" was a label put on a wide variety of work such as studies of research methods, analyses of concepts and ex post facto interpretations or explanations of correlations between variables. And a third way of defining "theory" is a "system of interrelated empirical propositions which do not include any limitations to a particular time or place" (Malewski, 2017, p. 421). What follows is a focus on this last category of theory where two famous symbolic-interaction sociologists reside.

The purpose of this article is to contribute an identification of the similarities between two theories of communication and social interaction, Homans' exchange theory and Goffman's dramaturgical analysis, and to offer an original argument that Homans' "covering law doctrine" could assimilate Goffman's. In addition, evidence is presented to support the similarity claim that Homans and Goffman, both micro sociologists, used an individual approach (Dillon, 2010; Lawler, Thye \& Yoon, 2008, P. 538) and the propositions of behavioral psychology to explain communication and interaction. Homans' theory is key to "...interpreting society as a series of interactions between people that are based on estimates of rewards and punishments" (Crossman, 2018, p. 1) and understanding and explaining the maximizing of the benefits and the minimizing of the costs (Cherry, 2018; Corbishley, 2016; Redman, 2015) in interpersonal encounters. The following discussion, however, begins with a summary of Goffman because it is his theory that it is argued can be assimilated by the "covering law doctrine".

\section{Brief Theoretical Positioning}

\subsection{Goffman's Dramaturgical Analysis}

Talk creates for the participant a world and a reality that has other participants in it. Joint spontaneous involvement is a unio mystic, a socialized trance. We must also see that a conversation has a life of its own and makes demands on its own behalf. It is a little social system with its own boundary-maintaining tendencies. (Goffman, 1967, p. 113)

Erving Goffman (1922-1982) was one of the most cited (Tyler, 2018; Pettit, 2011) and "influential American sociologists of the twentieth century" (Fine \& Manning, 2003, p. 34). Born in Canadian and influenced by George Herbert Mead and Herbert Blumer, he is best known for his social action rituals, "dramaturgical" approach, and "interaction orders" of face-to-face encounters in our heterogeneous world where different settings call for different forms of communication and activity, rather like a theater performance (Leeds-Hurwitz, 2017). He described people as actors on stage who used props at their disposal to influence a predictable definition of the situation (Oliver, Porock \& Oliver, 2006, p. 195).

Goffman's theoretical model continues to be the analytical lens used by scholars from different disciplines, most notably in the fields of political movements (Tyler, 2018), law school (Bliss, 2017), classical ballet (Whiteside \& Kelly, 2016), gambling (Shalin, 2016), horse training (Dellwing, 2016), communications and politics (Brown, 2010; Kravel-Tovi, 2012), nursing, hospitals and health care (Capps, 2016; Hays \& Weinert, 2006; O'Brien, Payne, Nolan \& Ingleton, 2010; Oliver, Porock \& Oliver, 2006), organizational deviance 
(Jensen \& Sandstrom, 2015) and psychoanalysis (Marcus, 2010). When life is viewed as a theatre, as it was by Goffman, the average person can find more meaning and live a better life when he/she can be expressive and impress others (Marcus, 2010, p. 758).

\subsection{Homans' Exchange Theory}

A man emits a unit of activity, however that unit be defined, and this unit is either reinforced or punished by one or more units of activity he receives from another man or by something he receives from the non-human environment. (Homans, 1961, p. 39)

For all actions taken by persons, the more often a particular action of a person is rewarded, the more likely the person is to perform that action. (Homans, 1974, p. 25)

Twelve years older, but outliving Goffman, was the American sociologist George C. Homans (1910-1989). Homans, influenced most by Lawrence Henderson and B. F. Skinner, focused on the creation of a unified social science based on his study of small groups and the communication and interaction of people in face-to-face situations. Social behaviorists have referred to Homans' analytical contribution as "exchange theory," or "social exchange theory," which is a "... social psychological perspective that explains social relationships as a process of negotiated exchanges between parties that is based on the concept of rewards, punishments and resources" (Rosenbaum, 2009, p. 39). Homans (1961) described it as a perspective that "envisages social behavior as an exchange or activity, tangible, or intangible, and more or less rewarding or costly, between at least two persons" (p. 13).

Except for contemporary social theory books (see Dillon, 2010; Delaney, 2005; Trevino, 2006; Ritzer, 2007; Ritzer \& Goodman, 2004), Homans is not discussed much anymore, yet his work continues to influence research in the areas of behavioral science theory (Malewski, 2017), social exchange on family farms (Gezelius, 2017), host-guest interaction (Capistrano \& Weaver, 2017), employee knowledge sharing (Serenko \& Bontis, 2016), organizational participation (Slack, Corlett \& Morris, 2015), political science (Cann \& Sidman, 2011), risk-taking and trust (Chen, 2011; Cheshire, Gerbasi \& Cook 2010), organizational behavior and industrial relations (Chen, 2011; Lawler, 2001), public relations (Corbishley, 2016) emotional affect and the micro social order (Kuwabara, 2011; Lawler, 2001), social justice (Hibbert, 2010) and health care (Cook, 2000; Nakonezny \& Denton, 2008).

\subsection{Filling a Literature Void}

Only once in the sociological literature does Homans come close to taking up the intellectual cudgels with Goffman. That singular moment was through Mitchell's (1978) Social Exchange, Dramaturgy and Ethnomethodology. It is exciting to imagine what might have occurred had Homans' "exchange theory" reviewed Goffman's "dramaturgical analysis" directly through primary sources. To satisfy that curiosity, this work partially fills that void by providing a Homansesque comment on some of Goffman's major ideas. The following Homansian assimilation of Goffman is naturally dominated by discussion of Homans' theory.

The major goal of this article is to represent Homans and use Homan's theory as the basis of reviewing Goffman. This is an admittedly risky task because Goffman himself once said that his work resisted pigeonholing (Fine \& Manning, 2003, p. 42). If Erving Goffman's major 
premises been made explicit (which they are not), his "theory" would turn out to be the same kind of law producing theory as Homans'. Not everyone would agree with this. Pettit (2011, p. 140), for example, does not believe that Goffman was focused on formulating universal laws.

\subsection{Some Similarities}

Both Goffman and Homans drew heavily upon others' fictional literature, fabricated anecdotes and case work (Tyler, 2018, p. 751; Love, 2013, p. 419; Delaney, 2005, p. 121; Trevino, 2009, p. 5), and they were both influenced by many of the same classical thinkers. They supported theory as being deductive explanatory and they were positivists (Homans more than Goffman) in the Hempelian and Braithwaite tradition. For example, in Strategic Interaction, Goffman spoke of "moves" in game theory and referred to Braithwaite (Goffman, 1969, p. 91). Homans, too, tried to establish law-like causal explanations of phenomena and both theorists promoted predictive propositions. In Homans' work, there are many examples that he drew from thermodynamics. Influenced by these examples, he then used the concept of "feedback" to discuss the circuit of mutual dependence he believed existed between certain variables.

\subsection{Some Bibliographical Differences}

While Homans was an advocate for a unified social science and was associated with "exchange theory" which he was the father of (although he regretted that his theory was given this label which was given by fellow sociologists) (Ritzer \& Goodman, 2004, p. 271), Goffman's most distinctive and important contribution to sociology was his dramaturgical model. He never sought to unify his work within a broad theory of society (Leib, 2017). "His goal was a natural history of communication among humans" (Pettit, 2011, p. 138). He thought that people intentionally foster and negotiate information about themselves by decoding facts and informing or misinforming others (Kravel-Tovi, 2012, p. 378).

Goffman, long thought of as a "cult" figure (Ritzer \& Goodman, 2004, p. 222) and an "outlaw theorist" (Fine \& Manning, 2003, p. 58), received his Ph.D. from the University of Chicago, a school that was renowned for its emphasis on the use of fieldwork as participant-observation. In contrast, Homans joined "The Society of Fellows" which was a small group of faculty and students at Harvard who dined together once a week to follow intellectual pursuits that were broader and "more adequate" (Delaney, 2005, p. 138) than the restrictive requirements for the $\mathrm{Ph} . \mathrm{D}$.

\subsection{Homans' Claim}

Homans believed that all the different schools of sociology used the propositions of behavioral psychology. He included in this claim; symbolic interactionism, phenomenology, ethnomethodology and, of course, his own "exchange theory." The only theory he excluded was societal functionalism, his term for Radcliff-Brown anthropology and the Parsonian sociology. While Homans did not endorse Goffman's sociology (Trevino, 2009, p. 9), he would have placed Goffman's dramaturgical analysis in the behavioral psychology category which Homans came to believe was the only defensible theory of social behavior. To Goffman's credit, he never systematically confronted other sociological theorists (Fine \& 
Manning, 2003, p. 34).

\section{From Analytical Functionalism to Propositions}

The sequence of Homans' oeuvre begins from what could be called a simple analytical functionalism. In The Human Group (1950) he drew heavily upon pragmatism and some social anthropology, particularly the functionalism of Malinowski and Radcliff-Brown (Delaney, 2005, p. 140). Goffman (1959, pp. 26-35), similarly, in his work The Presentation of Self in Everyday Life, used both Durkheim and Radcliff-Brown as did Homans. Homans was listed in some early theory text books as a macro-functionalist. He understood how people might have come to think this way if they only read The Human Group, but as his thinking matured he discovered an intellectual difference between the functionalisms of Malinowski and Radcliff-Brown (Delaney, 2005, p. 140). Homans admitted that The Human Group lacked sophistication, but it became a trademark of all his work, it was clear and easy to read. It lacked the strong hedonism of his later work, but in it he tried to describe group behavior and set forth some propositions that he developed more fully in his next book, Social Behavior: Its Elementary Forms (1961).

Goffman, also, set forth some propositions that abound in his work. From Goffman's (1959 The Presentation of Self, one can find many, for example, "the higher the rank or temporary ceremonial status of the visitor, the more likely he was to receive an offering near the liquor end of the continuum" (Goffman, 1959, p. 29) and "the more closely the impostor's performance to the real thing, the more intensely we may be threatened" (Goffman, 1959, p. 59) and "the larger the number of matters and the larger the number of acting parts which fall within the domain of the role or relationship, the more likelihood it would seem, for points of secrecy to exist" (Goffman, 1959, p. 64). There are propositions like these in most all of Goffman's books. They are in Stigma: Notes on the Management of Spoiled Identity (1963, pp. 64, 107) and Encounters (1961, pp. 13, 64) and Behavior in Public Places (1963, pp. 85, $93,95)$ and Strategic Interaction $(1969$, pp. 62, 77) should the reader require more evidence.

The propositions were Homans' attempt to answer some questions he put before his fellow sociologists: "What single general proposition about human behavior have we established? Has sociology succeeded in making even one statement about the way men act that can be relied on in all circumstances where it should apply? Has it made one theoretical formulation that is uniformly descriptive?" (Homans, 1950, p. 6). The only answer Homans could honestly arrive at was "no." He admitted that he didn't understand what the word "theory" meant when he wrote this heavily inductive book in which he studied five organized and functionalized small groups by using the case method. But later, Homans (1985) defined theory as "a deductive system, which is also called the covering-law doctrine" (p. 1).

Like the early Homans, Goffman was aware of the significance of induction. In The Presentation of Self in Everyday Life, he wrote, "The issues dealt with by stage-craft and stage management are sometimes trivial but they are quite general; they seem to occur everywhere in social life, providing a clear-cut dimension for formal sociological analysis" (Goffman, 1959, p. 15). In addition to his use of participant-observation, which is sometimes seen as an unacknowledged source of Goffman's modeling (Pettit, 2011, p. 140), Goffman 
drew on many of the same methods, case descriptions and authors as did Homans. In The Presentation of Self in Everyday Life, Goffman (1959), in reference to Whyte's Street Corner Society, said, "it would be more prudent, then, to begin with smaller units... and document comparisons and changes in a modest way by means of the case-history method" (p. 245). In Encounters, Goffman (1961) mentioned the Nortons from Whyte's (1943, p. 48) Street Corner Society and spoke of the normative and punishing behavior of "binging" as discussed by Roethlisberger and Dickson (1939) in Management and the Worker. These were two of the five cases Homans used in The Human Group. Behavior in Public Places (Goffman, 1963), however, is a good example of how Goffman quoted from fictitious situations in literature rather than using the quality cases throughout like Homans did. Goffman drew upon Charles Dickens, Samuel Beckett and Herman Melville, for example. In Interaction Ritual, Goffman (1967) wrote, "One objective in dealing with these data is to describe the natural units of interaction" (p. 1).

Homans (1984) believed that he, in The Human Group, did a much better job than either Marx, Spencer or Toynbee in serving the basic scientific functions of criticism, theory-verification and result-prediction. Homans (1950) thought that "...the only historical continuity of men in society is that of small groups. The small group is the basic social unit. And it may be that by studying them we can arrive at theoretical statements which describe society" (p. xii). The importance of The Human Group is that, different as those groups were, their behavior showed fundamental similarities; they revealed social uniformities. An example of this is one of Homans' (1950) derived propositions: "Persons who interact frequently with one another tend to like one another" (p. 112). To arrive at this and other propositions, Homans studied the mutual dependence of "activity," "interaction," and "sentiment."

Goffman's (1959) definition of "interaction” was, “...all the interaction which occurs throughout any one occasion when a given set of individuals are in one another's continuous presence" (1959, p. 15). This definition is fundamentally the same as Homans'. Goffman's definition of performance is equivalent to Homans' "activity." Goffman (1959) wrote, “... 'performance' may be defined as all the activity of a given participant on a given occasion which serves to influence in any way any of the other participants" (p. 15). To express the relationship between these concepts, Goffman (1959) wrote in The Presentation of Self, "for if the individual's activity is to become significant to others, he must mobilize his activity so that it will express during the interaction what he wishes to convey" (p. 30).

\section{Balance}

The second major work in the sequence of Homans' ultimate conclusion that the propositions of behavioral psychology and elementary economics (rational choice theory) made up the only defensible theory (Ritzer \& Goodman, 2004, p. 271) of social behavior was Social Behavior: Its Elementary Forms (1961). In this book, Homans abandoned the functionalist method in favor of an exchange theory. The whole idea of balance was a functional concept, and Goffman, like Homans, used the notion as a central component of his theories. A key issue for Goffman was the problem of solidarity, and the behaviors which interactionists used in trying to maintain harmonious or "acceptable" rules of interaction. 
There are great examples of this to be found in all of Goffman's books, but Homans limited his comments to Goffman's (1963) Behavior in Public Places where Goffman wrote, “...out of regard for harmony in the scene he is required to compromise and endanger himself further by putting on an air of one who belongs when it can be shown that he doesn't" (p. 11). Goffman quite frequently quoted from books on etiquette to make this point and even referred to Adam Smith, Charles H. Cooley and George H. Mead in his discussion of the "mutuality of immediate social interaction" (Goffman, 1963, p. 16). One of Goffman's major themes was that there were rules for social interchanges that existed to keep the social machinery rolling smoothly, orderly and balanced (Cook, 2000, p. 687). The success of this was in playing one's role well.

Homans' exchange theory had not been labeled or fully developed during Goffman's early writing so direct reference to it in Goffman's work cannot be found. The following four examples indicate Goffman's use of Homans' theory. In The Presentation of Self, Goffman (1959) wrote, "...the capacity to convey effectively a definition of the situation may be of little use if one is not in a position to give example, exchange, punishment, etc.” (p. 241). In Interaction Ritual: Essays on Face to Face Behavior, Goffman (1967) stated, “...different individuals and groups have somewhat different personal baselines from which to measure risk and opportunity (p. 157). In Behavior in Public Places, Goffman (1963) explained, "...there are reasons why someone able to be accessible should be willing to pay the price of remaining inaccessible" (p. 107). And in Strategic Interaction he referred to the whole idea of exchange as “... a system which usually balances indulgences” (Goffman, 1969, p. 38).

Homans set up his behavioral stance very quickly and, in fact, devoted the entire second chapter of The Elementary Forms to the findings of behavioral psychologists to animal behavior. Like The Human Group, this book also dealt with groups, although in The Elementary Forms the groups were much smaller. While The Human Group was mostly descriptive, The Elementary Forms was mostly explanatory (Trevino, 2009, p. 6). It is in this book that Homans tried to explain why the major propositions were accepted. To do this, he set up more general propositions from which he logically deduced empirical ones under given conditions. He believed that to deduce them was to have successfully explained them. He wrote, "The set of general propositions I shall use in this book envisages social behavior as an exchange of activity, tangible or intangible, and more or less rewarding or costly, between at least two persons" (Homans, 1961, p. 13). One of the five propositions on human exchange Homans discovered is, "The more often within a given period of time a man's activity rewards the activity of another, the more often the other will emit the activity" (1961, p. 54).

\section{Behaviorism}

Homans (1983), in The Elementary Forms, considered all human activity as being learned behavior. He wrote, "The heart of behaviorism is a sequence over time: the action of an organism, the consequences for it of that action and the feedback from the consequences, which may affect the future behavior of the organism" (p. 35). He emphasized the triple contingency of (1) stimulus, (2) activity and (3) reinforcement (Trevino, 2009, p. 4). For him, social exchange allows for one person to provide a benefit to another. There is an unspecified obligation (Nakonezny \& Denton, 2008, p. 407), unlike in economic exchange, because the 
exact nature of the payback is not specified.

The importance of learning theory, which in psychology corresponds to symbolic interactionism (Delaney, 2005, p. 108), is also evident throughout all of Goffman's work. Stigma (1963), however, provided some particularly vivid illustrations. In this work, for example, Goffman wrote, “... an orphan learns that children naturally and normally have parents, even while he is learning what it means not to have any" (Goffman, 1963, p. 32). Another case involved entering public school that "...is often reported as the occasion of stigma learning, the experience sometimes coming very precipitously on the first day of school, with taunts, teasing, ostracism, and fights" (Goffman, 1963, p. 33). And, finally, Goffman (1963) quoted, "I managed to keep Mary from knowing my eyes were bad through two dozen sodas and three movies. I used every trick I had ever learned" (p. 88). So, Goffman, too, was interested in sequential behavior. In Interaction Ritual, he said, “...we need to identify the countless patterns and natural sequences of behavior occurring whenever persons come into one another's immediate presence" (Goffman, 1967, p. 2).

Homans also considered hedonistic and rational animals who were usually interested in determining what's in it for them before they act. The whole basis for the individualistic approach was that people have rational-choice incentives to exchange (Lawler, Thye \& Yoon, 2008, p. 522) and people reward each other (Lawler, 2001, p. 323). Goffman also discussed this hedonism. Goffman (1959) wrote in The Presentation of Self in Everyday Life, “.... raw recruit who initially follows army etiquette in order to avoid physical punishment and eventually comes to follow the rules so that his organizations will not be shamed and his officers and fellow soldiers will respect him” (p. 20). He said in Interaction Ritual, “...in many societies, members know the value of voluntarily making a gracious withdrawal before an anticipated threat of face has had a chance to occur" (Goffman, 1967, p. 15).

There are, of course, many other cases of Goffman's belief that man is hedonistic. A few more examples can be found in Encounters when he said, "...games can be fun to play, and fun alone is the approved reason for playing them" (1961, p. 17). "Flooding out" (Goffman, 1961, p. 55) is another example of Goffman's hedonism. One final illustration is in Behavior in Public Places where he is talked about focused interaction and some reasons why an individual is obliged to respond to requests for face engagement. Goffman (1963) wrote, "He owes this to himself because often it will be through such communication that his own interests can be served..." (p. 104).

The individual's desire for profit is just as much a concern for Goffman as it was for Homans. Goffman (1959) said in Presentation of Self, “....in addition to secret pleasures and economies, the performer may be engaged in a profitable form of activity that is concealed from his audience..." (p. 43). And in Interaction Ritual, where Goffman (1967) spoke of consequentiality, he wrote, "Objective value and utility are both means of establishing instantaneous equivalents for consequences that are to be actually felt over time" (p. 160). One of the major profitable commodities was the prevention of embarrassing blunders.

The concept of reward runs throughout Goffman. In describing a technique used by women to give the impression of flightiness and reconfirm in male superiority the minds of men, 
Goffman (1959) wrote in The Presentation of Self in Everyday Life, "One of the nicest techniques is to spell long words incorrectly once in a while. My boyfriend seems to get a great kick out of it and writes back, 'Honey, you certainly don't know how to spell'” (p. 39). He wrote in Stigma, "The individual is told that if he adopts the right line..., he will have come to terms with himself and be a whole man; he will be an adult with dignity and self-respect" (Goffman, 1963, p. 123). In Interaction Ritual, Goffman (1967) said, "Once individuals enter a conversation they are obliged to continue until they have the kind of basis for withdrawing that will neutralize the potentially offensive implications of taking leave of others" (p. 120). Other examples can be found in Interaction Ritual (Goffman, 1967, pp. 24, 36, 101) and in Encounters (Goffman ,1961, pp. 40, 48) and in Behavior in Public Places (Goffman, 1963, pp. 34, 195).

The cost of certain behavior was an important consideration for Goffman. In The Presentation of Self, he wrote, “.... television repairman is advised by his public relations counsels that the screws he fails to put back into the set should be kept alongside his own so that the un-replaced parts will not give an improper impression" (Goffman, 1959, p. 56). And in Stigma, Goffman (1963) said, "Any male who fails to qualify in any of these ways (referring to the typical-all-American male) is likely to view himself - during moments at least - as unworthy, incomplete, and inferior" (p. 128).

In 1964, Homans gave his American Sociological Association Presidential Address, "Bringing Men Back In." In this address he tried to put down the functionalist school, disassociate himself from it and attempt to get his colleagues to adopt (for the sake of unity in the discipline) the psychological propositions, behavioral explanations and logical-deductive models he had been using for years. Then, Homans (1982) wrote "The Present State of Sociological Theory" in which he stated quite unequivocally that "Intellectually, sociology is in greater disarray than usual" (p. 285). He also reaffirmed his position that the definition of a theory of a phenomenon is an explanation of phenomenon. For him, an explanation consisted of a set of at least three propositions which must meet at least two conditions: "(1) they must state a relationship between at least two variables and (2) they must begin to state what the relationship is. A completed theory is a deductive system and the only defensible one has its basis in the principles of behavioral psychology" (1982, p. 285). Like Homans, Goffman's description of an effective actor who is rewarded for good performance and continues to behave in the same manner with the same results is an example of Goffman's inexplicit use of the deductive-nomological model. One only has to refer to Homans' "The Present State of Sociological Theory" (1982) to see how Homans made explicit what he kept inexplicit.

Not everyone has agreed with Homans. One of his most ardent critics was A. R. Louch who believed that Homans' propositions were tautologies. Homans thought Louch's criticisms were unfair. Louch's Explanation and Human Action (1966) attacked Homans' The Human Group (1950). Homans admitted in Elementary Forms that many of his ideas originally put forth in The Human Group were only basic and needed development. He believed that Louch made no reference at all to Elementary Forms. He also thought Louch (1966) attacked his propositions proposed in The Human Group by calling them "general laws that don't stand" (17). Homans claimed he never meant them to be laws and Louch would have known that if 
he had seen the covering laws that Homans supplied in Elementary Forms.

\section{Conclusion}

Both Homans' and Goffman's theory of communication recognizes human uniqueness. Homans (1985) basically believed that people's behavior is determined and that people "are often equally persuaded, but neither we nor they always know the detailed, including historical, given conditions in their case to which the behavioral laws are to be applied. This allows them the illusion of freedom of choice - and a good thing, too" (p. 1). Goffman, too, talked about this freedom in Encounters, but he begged the question. He said, "Individuals are almost always free to modulate what they are required to do, being free, thus, to give way to the wider constraints of their multiple self-identifications" (Goffman, 1961, p. 151). Also, in Frame Analysis, Goffman (1974) said, "The manner in which the role is performed will allow for some expression of personal identity...” (p. 573).

Homans admitted that not everything could be explained by his "covering laws" theory. He could not explain creation, for example. "The reason is that we often do not have the information about the particular given conditions within which the covering laws are to be applied. I myself, as an English historian, cannot explain why William the Conqueror won the Battle of Hastings. But I can explain a great many more everyday phenomena" (Homans, 1985, p. 1). But, even Goffman's dramaturgical analysis cannot explain creativity. He devoted his life to studying the intentional creation of "effects" or "impressions" in communication.

The evidence has been presented here that Homans" "exchange theory" could assimilate Goffman's "dramaturgical analysis." Some scholars might disagree. Towards the end of his career, Homans was accepting and pushing the covering-law doctrine, and he thought that most sociological theorists were not doing so (Homans, 1985, p. 1). One would reasonably expect that he thought Goffman did not. He probably believed Goffman's dramaturgical analysis was enthymematic with implied, but unstated premises. The argument has been made that if Goffman's premises are implied, and if they have a hedonistic basis, they are basically the same as Homans'.

\section{References}

Abrahamson, B. (1970). Homans on exchange: Hedonism revived. American Journal of Sociology, 76(2), 273-285. https://doi.org/10.1086/224933

Bliss, J. (2017). Divided selves: Professional role distancing among law students and new lawyers in a period of market crisis. Law \& Social Inquiry, 42(3), 855-897. https://doi.org/10.1111/1si.12204

Brown, R. E. (2010). Conjuring unity: The politics of the crowd and the poetics of the candidate. American Behavioral Scientist, 54(4), 382-393. https://doi.org/10.1177/0002764210381714

Burgess, R. L., \& Bushell, D., Jr. (1993). Behavioral sociology: The experimental analysis of social process. New York, NY: Columbia University Press.

Capistrano, R. C., \& Weaver, A. (2017). Host-guest interactions between first-generation immigrants and their visiting relatives: Social exchange, relations of care and travel. 
International Journal of Culture, Tourism and Hospitality Research; Bradford, 11(3), 406-420. https://doi.org/10.1108/IJCTHR-11-2016-0115

Capps, D. (2016). The mortification of the self: Erving Goffman's analysis of the mental hospital. Pastoral Psychology, 65(1), 103-126. https://doi.org/10.1007/s11089-015-0665-1

Cherry, K. (2018). Social exchange theory: How social exchange theory influences relationships.

Retrieved

from

http://www.verywellmind.com/what-is-social-exchange-theory-2795882?print

Cheshire, C., Gerbasi, A., \& Cook, K. S. (2010). Trust and transitions in modes of exchange. Social Psychology Quarterly, 73(2), 176-195. https://doi.org/10.1177/0190272509359615

Corbishley, R. (2016). Interpersonal communication - Social exchange theory. Retrieved from https://linkedin.com/pulse/interpersonal-communication-social-exchange-theory-robert

Crossman, A. (2018). Understanding social exchange theory. Retrieved from http://www.thoughtco.com/social-exchange-theory-3026634?print

Delaney, T. (2005). Contemporary social theory: Investigation and application. Upper Saddle River, NJ: Pearson, Prentice Hall.

Dellwing, M. (2016). A guide to training your own horses: The Flaneur approach and Erving Goffman's uninhibited research practices in sociology. Symbolic Interaction, 39(1), 126-142. https://doi.org/10.1002/symb.216

Dillon, M. (2010). Introduction to sociological theory. West Sussex, UK: John Wiley, Ltd.

Fine, G., \& Manning, P. (2003). Erving Goffman. In G. Ritzer (Ed.), The Blackwell companion to major contemporary social theories. (pp. 34-58). Malden, MA: Blackwell Publishing.

Gezelius, S. (2017). Considerate exchange: Exploring social exchange on family farms. Journal of Family and Economic Issues, 38, 18-32. https://doi.org/10.1007/s10834-016-9496-1

Goffman, E. (1963). Behavior in public places. London, England: Collier-MacMillan, Ltd.

Goffman, E. (1961). Encounters. Indianapolis, IN: The Bobbs-Merrill Co., Inc.

Goffman, E. (1981). Forms of talk. Philadelphia, PA: University of Pennsylvania Press.

Goffman, E. (1974). Frame analysis. Cambridge, MA: Harvard University Press.

Goffman, E. (1967). Interaction ritual: Essays on face to face behavior. Chicago, IL: Aldine Publishing Company.

Goffman, E. (1963). Stigma: Notes on the management of spoiled identity. Englewood Cliffs, NJ: Prentice-Hall.

Goffman, E. Strategic interaction. (1969). Philadelphia, PA: University of Pennsylvania Press.

Goffman, E. (1959). The presentation of self in everyday life. New York, NY: Doubleday and Co., Inc. 
Gray, D. (1971). Some comments concerning Maris on 'logical adequacy'. American Sociological Review, 36(4), 706-709. https://doi.org/10.2307/2093601

Hall, S., \& Lindzey, G. (1957). Theories of personality. Hoboken, NJ: John Wiley \& Sons, Inc.

Hamblin, R. L., \& Kunkel, J. H. (1977). Behavioral theory in sociology. New Brunswick, NJ: Transaction Books.

Hibbert, N. (2010). Exchange and social justice. Theoria: A Journal of Social and Political Theory, 57(122), 26-48. https://doi.org/10.3167/th.2010.5712204

Homans, G. C. (1964). Bringing men back in. American Sociological Review, 29(6), 809-818. https://doi.org/10.2307/2090864

Homans, G. C. (1984). Coming to my senses: The autobiography of a sociologist. New Brunswick, NJ: Transaction Books.

Homans, G. C. (1966). Reply to Razak. American Sociological Review, 31(4), 343-344. Retrieved from http://www.jstr.org/stable/2090778

Homans, G. C. (1972). Review Symposium - Beyond freedom and dignity by B. F. Skinner. American Journal of Sociology, 78(3), 696-708. https://doi.org/10.1086/225377

Homans, G. C. (1961). Social behavior: Its elementary forms. New York, NY: Harcourt, Brace \& World, Inc.

Homans, G. C. (1983). Steps to a theory of social behavior. Theory and Society, 12(1), 1-45. https://doi.org/10.1007/BF00173622

Homans, G. C. (1950). The human group. New York, NY: Harcourt Brace \& World, Inc.

Homans, G. C. (1982). The present state of sociological theory. The Sociological Quarterly, 23(3), 285-299. https://doi.org/10.1111/j.1533-8525.1982.tb01013.x

Homans, G. C. (1985). Unpublished letter to Forbes Farmer.

Jensen, T., \& Sandstrom, J. (2015). Normal deviants and Erving Goffman: Extending the literature on organizational stigma. Nordic Journal of Working Life Studies, 5(4), 125-142. https://doi.org/10.19154/njwls.v5i4.4847

Joachim, H. H. (1998). Aristotle: Nicomachean ethics. (D. Ryoss, Trans.). New York, NY: Oxford University Press.

Kravel-Tovi, M. (2012). Rite of passing: Bureaucratic encounters, dramaturgy, and Jewish conversation in Israel. American Ethnologist, 39(2), 371-388. https://doi.org/10.1111/j.1548-1425.2012.01370.x

Kuwabara, K. (2011). Cohesion, cooperation, and the value of doing things together: How economic exchange creates relational bonds. American Sociological Review, 76(4), 560-580. https://doi.org/10.1177/0003122411414825

Lawler, E. J. (2001). An affect theory of social exchange. American Journal of Sociology, 107(2), 321-352. https://doi.org/10.1086/324071 
Lawler, E. J., Thye, S., \& Yoon, J. (2008). Social exchange and micro social order. American Sociological Review, 73(4), 519-542. https://doi.org/10.1177/000312240807300401

Leib, R. S. (2017). Spaces of the self: Foucault and Goffman on the micro-physics of discipline. Philosophy Today; Charlottesville, 61(1), 189-210. https://doi.org/10.5840/philtoday2017321153

Louch, A. R. (1966). Explanation and human action. Berkeley, CA: University of California Press.

Love, H. (2013). Close reading and thin description. Public Culture, 25, 401-434. https://doi.org/10.1215/08992363-2144688

Marcus, P., \& Marcus, G. (2010). Psychoanalysis as theater: The practical application of acting theory to psychotherapy and real life. Psychoanalytic Review, 97(5), 757-787. https://doi.org/10.1521/prev.2010.97.5.757

Maris, R. W. (1971). Second thoughts: Uses of logic in theory construction. American Sociological Review, 36(4), 713-715. https://doi.org/10.2307/2093604

Maris, R. W. (1970). The logical adequacy of Homans' social theory. American Sociological Review, 35(6), 1069-1081. https://doi.org/10.2307/2093383

McGinnies, E. (1970). Social behavior: A functional analysis. Boston, MA: Houghton Mifflin Co.

Merton, R. K. (1957). Social theory and social structure. New York, NY, The Free Press.

Mitchell, J. (1978). Social exchange, dramaturgy and ethnomethodology. New York, NY: Elzevier.

Nakonezny, P. A., \& Denton, W. H. (2008). Marital relationships: A social exchange theory perspective. The American Journal of Family Therapy, 36(5), 402-412. https://doi.org/10.1080/01926180701647264

O'Brien, T., Payne, S., Nolan, M., \& Ingleton, C. (2010). Unpacking the politics of evaluation: A dramaturgical analysis. Evaluation, 16(4), 431-444. https://doi.org/10.1177/1356389010380002

Oromaner, M. J. (1968). The most cited sociologists: An analysis of introductory text citations. The American Sociologist, 3(2), 124-126.

Pettit, M. (2011). The con man as model organism: The methodological roots of Erving Goffman's dramaturgical self. History of the Human Sciences, 24(2), 138-154. https://doi.org/10.1177/0952695111398828

Price, R. (1971). On Maris and the logic of time. American Sociological Review, 36(4), 711-712. https://doi.org/10.2307/2093603

Razak, W. N. (1966). Razak on Homans. American Sociological Review, 31(4), 542-543.

Redmond, M. (2015). Social exchange theory. English Technical Reports and White Papers. 5. Retrieved from http://lib.dr.iastate.edu/engl_reports/5 
Roethlisberger, F. J., \& Dickson, W. J. (1939). Management and the worker. Cambridge, MA: Harvard University Press.

Serenko, A., \& Bontis, N. (2016). Negotiate, reciprocate, or cooperate? The impact of exchange modes on inter-employee knowledge sharing. Journal of Knowledge Management, 20(4), 687-712. https://doi.org/10.1108/JKM-10-2015-0394

Shalin, D. N. (2016). Erving Goffman, fateful action, and the Las Vegas gambling scene. UNLV Gaming Research \& Review Journal, 20(1), 1-38.

Skidmore, W. (1975). Theoretical thinking in sociology. Cambridge, England: Cambridge University Press.

Slack, R. E., Corlett, S., \& Morris, R. (2015). Exploring employee engagement with (corporate) social responsibility: A social exchange perspective on organizational participation. Journal of Business Ethics, 127(3), 537-548. https://doi.org/10.1007/s10551-014-2057-3

Sorokin, P. (1966). Sociological theories of today. New York, NY: Harper and Row, Publishers.

Trevino, A. J. (2009). George C. Homans, the human group and elementary social behavior. The Encyclopedia of Informal Education. Retrieved from http://infed.org/mobi/george-c-homans-the-human-group-and-elementary-social-behaviour/

Turk, H., \& Simpson, R. L. (1971). Institutions and social exchange: The sociologies of Talcott Parsons and George C. Homans. New York, NY: Bobbs-Merrill Co., Inc.

Turner, S. (1971). The logical adequacy of 'the logical adequacy' of Homans' social theory. American Sociological Review, 36(4), 709-711. https://doi.org/10.2307/2093602

Tyler, I. (2018). Resituating Erving Goffman: From stigma power to black power. Sociological Review, 66(4), 744-765. https://doi.org/10.1177/0038026118777450

Whiteside, B., \& Kelly, J. (2016). The presentation of self in the classical ballet class: Dancing with Erving Goffman. Research in Dance Education, 17(1), 14-27. https://doi.org/10.1080/14647893.2015.1110570

Whyte, W. F. (1943). Street corner society. Chicago, IL: University of Chicago Press.

\section{Copyright Disclaimer}

Copyright for this article is retained by the author(s), with first publication rights granted to the journal.

This is an open-access article distributed under the terms and conditions of the Creative Commons Attribution license (http://creativecommons.org/licenses/by/3.0/). 